\title{
Caracterização molecular e laboratorial da talassemia beta e da interação hemoglobina S/talassemia beta
}

\author{
Molecular and laboratory characterization of beta thalassemia and Hb S/beta thalassemia
}

Zama Messala Luna da Silveira

Orientador: Tereza Maria Dantas de Medeiros

\section{Resumo}

A talassemia beta ocorre devido à diminuição $(ß+)$ ou ausência (ß0) de síntese de cadeias beta levando a uma menor produção de hemoglobina. Até o momento, foram descritas mais de 200 tipos de mutações diferentes para a talassemia beta sendo resultantes em sua maioria, de mutações de ponto caracterizadas pela troca de um único nucleotídeo na sequência gênica. $\mathrm{O}$ objetivo principal deste estudo foi realizar a caracterização molecular e laboratorial em indivíduos heterozigotos e homozigotos da talassemia beta e em portadores da interação hemoglobina S/talassemia beta. Foram incluídos 48 indivíduos ( 35 heterozigotos, 4 homozigotos e 9 com interação $\mathrm{HbS} /$ talassemia beta) atendidos no Laboratório Integrado de Análises Clínicas (UFRN) e realizados os seguintes exames laboratoriais: eritrograma, eletroforese de hemoglobina, dosagem das hemoglobinas A2 e Fetal, dosagem de ferritina sérica. A caracterização molecular foi realizada por reação em cadeia da polimerase/análise de restrição de fragmentos polimórficos - PCR /RFLP mediante digestão com enzimas de restrição específicas para as mutações IVS-1 nt 1, IVSI-1 nt 6 e códon 39. Dentre os 35 heterozigotos, 13 $(37,1 \%)$ apresentaram a mutação IVS-1 nt 6, 15 (42,9\%) a IVS-1 nt 1 e $7(20 \%)$ eram portadores de outras mutações não identificadas com a técnica utilizada. Os quatro pacientes homozigotos apresentaram a mutação IVS-1 nt 6 , enquanto $6(66,7 \%)$ dos indivíduos com $\mathrm{HbS} /$ talassemia beta tinham a mutação IVS-1 nt 1 . A códon 39 não foi detectada em nenhum dos pacientes investigados. Ao comparar os dados laboratoriais entre os indivíduos heterozigotos para as mutações IVS-1 nt 1 e IVS-1 nt 6 observou-se que os heterozigotos da mutação IVS-1 nt 1 apresentaram valores médios de VCM e HCM significativamente menores $(p=0,023$ e 0,007 , respectivamente) e hemoglobina $\mathrm{A} 2$ significativamente mais elevados $(\mathrm{p}<0,001)$ quando comparados aos heterozigotos da mutação IVS-1 nt 6. A técnica de PCR/RFLP se mostrou útil para a identificação da presença ou ausência das mutações IVS-1 nt 6 IVS1 nt 1 e códon 39 na maioria dos pacientes investigados. O presente estudo é o primeiro trabalho realizado no estado do Rio Grande do Norte para identificação das mutações da talassemia beta e constitui importante contribuição para o conhecimento do perfil molecular da talassemia beta em nosso país.

Descritores: Talassemia beta; Mutação; Polimorfismo de fragmento de restrição; Reação em cadeia da polimerase

\section{Abstract}

Beta thalassemia arises as a consequence of the reduction $(ß+)$ or absence $(ß 0)$ of beta globin chain synthesis and an overall reduction in hemoglobin synthesis. Currently, over 200 different molecular defects that cause beta thalassemia have been identified. Most of these defects are derived from point mutations characterized by the exchange of a single nucleotide in the gene sequence. The aim of this study was to perform molecular and laboratory characterization of beta thalassemia in heterozygous and homozygous individuals and in beta thalassemia associated to $\mathrm{S}$ hemoglobin. Forty-eight individuals ( 35 heterozygotes, 4 homozygotes and 9 with $\mathrm{HbS} /$ beta thalassemia) referred to the Integrated Laboratory of Clinical Analysis (UFRN) were included in this study. Blood samples were submitted to the following examinations: red blood cell counts, hemoglobin electrophoresis at alkaline $\mathrm{pH}$ and measurements of $\mathrm{HbA} 2, \mathrm{HbF}$ and serum ferritin. Molecular characterization was performed by PCR-RFLP, which involves digestion with specific restriction enzymes for the IVS-1 nt 1 , IVS- 1 nt 6 and codon 39 mutations. Of the 35 heterozygotes,

Dissertação apresentada ao Programa de Pós-Graduação em Ciências Farmacêuticas da Universidade Federal do Rio Grande do Norte para obtenção do título de Mestre em Ciências Farmacêuticas.

Suporte Financeiro: Conselho Nacional de Desenvolvimento Científico e Tecnológico (CNPq) Coordenação de Aperfeiçoamento de Pessoal de Nivel Superior (Capes)

Correspondência: Tereza Maria Dantas de Medeiros

Departamento de Análises Clínicas e Toxicológicas - Universidade Federal do Rio Grande do Norte

Rua General Gustavo Cordeiro de Farias, s/n-1 $1^{\circ}$ andar

59010-180 - Natal (RN), Brasil

E-mail:tdantas@ufrnet.br 
$37.1 \%$ had the IVS- 1 nt 6 mutation, $42.9 \%$ had IVS- 1 nt 1 and $20 \%$ were carriers of other mutations that were not identified by the technique employed. The four homozygous patients presented with the IVS-1 nt 6 mutation, while $6(66.7 \%)$ of the individuals with $\mathrm{S}$ beta thalassemia had the IVS-1 nt 1 mutation. Codon 39 mutations were not detected in any of the patients investigated. Comparison of laboratory data between heterozygous individuals with IVS-1 nt 1 and IVS-1 nt 6 mutations showed that heterozygotes for the IVS$1 \mathrm{nt} 1$ mutation had significantly lower mean MCV and MCH levels $(\mathrm{p}=0.023$ and 0.007 , respectively) and significantly higher hemoglobin A2 $(p<0.001)$ when compared to heterozygotes for the IVS-1 nt 6 mutation. PCR-RFLP was useful in identifying the presence or absence of IVS-1 nt 6, IVS-1 nt 1 and codon 39 mutations in most of the patients investigated here. This is the first study conducted in the state of Rio Grande do Norte, Brazil aimed at identifying beta thalassemia mutations and represents an important contribution to knowledge regarding the molecular profile of beta thalassemia in Brazil.

Keywords: Beta-thalassemia; Mutation; Polymorphism, restriction fragment length; Polymerase chain reaction

\begin{abstract}
Avaliação: A RBHH publica os resumos e abstracts de teses da área apresentados em entidades que tenham programas de pós-graduação reconhecidos pelo $\mathrm{MEC/Capes} \mathrm{e} \mathrm{considera} \mathrm{a} \mathrm{obtenção} \mathrm{do} \mathrm{título}$ suficiente para sua publicação na forma como se propõe a seção.
\end{abstract}

Recebido: $1 / 09 / 2010$

Aceito: 10/09/2010 